\title{
IMPACT OF MAKER-SPACE PROJECT TO PROVIDE COMPUTER SCIENCE EDUCATION TO MIDDLE SCHOOL STUDENTS IN THE ALABAMA BLACK BELT REGION
}

\author{
Linda P. Thurston ${ }^{1}$, Martha Escobar ${ }^{2}$, \& Mohammed Qazi ${ }^{3}$ \\ ${ }^{1}$ Kansas State University, Professor Emerita (USA) \\ ${ }^{2}$ Oakland University, Professor (USA) \\ ${ }^{3}$ Tuskegee University, Associate Professor (USA)
}

\begin{abstract}
This paper describes a program to introduce computer science (CS) to middle school students in rural Alabama, USA, and presents research on the impact of the program on teachers and students. The hands-on program established a dedicated area equipped with grade-appropriate CS resources, in which students receive mentored, structured, and continuous hands-on activities using the Micro:bit system. The goal was to have students engage in "learning CS through making", a pedagogical approach grounded in educational research that is expected to promote deep awareness, interest, skills, and learning about CS. The teachers participated in intensive professional development and received regular follow-ups from the course instructors. Researchers utilized a mixed method, repeated measures design to investigate the impact of the project on teachers and their students. The main research question is: What is the impact of the Maker-Space Project on participating middle-school teachers and their students?

Teacher attitudes and skills were measured at baseline and at two points in the first 2 years of the project. Other measures related specifically to the teacher professional development (PD). A survey was used to collect student data at participating schools. All students completing the $8^{\text {th }}$ grade were surveyed to collect baseline and comparison data. The survey included demographic data; prior experience with computing; and confidence, enjoyment, attitudes, and identity. In addition, pre-post survey data from students in the maker-space course was collected and analyzed. Post-course student data was compared to the baseline and comparison group data.

Researchers also visited the schools to observe the maker-space classrooms, visit with students and interview teachers. Researchers talked to the students and videotaped their discussions and their demonstrations of their projects. They also interviewed the teachers using a semi-structured protocol.

The professional development positively impacted the teachers' understanding of computer science and their use of active learning and hands-on learning in their own classrooms. The teachers reported being optimistic about their own ability to learn computer science education content and about their ability to teach the content to their $8^{\text {th }}$ grade students. Teachers reported changes in skills, competencies, interests and behaviors of their students. The teachers are pleased with the progress of their students in learning about computer science, especially coding. Working cooperatively, creative problem solving, and classroom engagement were behaviors seen in the Makerspace classrooms. Teachers reported seeing increased interest taking courses in high school and in computer science careers.
\end{abstract}

Keywords: Computer science education, middle school, educational research.

\section{Introduction}

The National Science Foundation (NSF) of the U.S. government funded a project to develop, implement, study and evaluate a program that to provide access to hands-on computer science (CS) education to students in middle schools. The project team developed a makerspace-based CS curriculum that is tied to the standards contained in the Alabama Digital Literacy and Computer Science (DLCS) Course of Study, leading to a stand-alone CS course called "CS Makers". The project took place in school districts of the Alabama Black Belt region, a region of the state with high minority and poverty rates. Teachers in four middle-school classrooms participated in professional development and established a dedicated area in their schools. The goal was to have students engage in "learning CS through making", a pedagogical approach grounded in educational research that is expected to promote deep awareness, interest, skills, and learning about CS (Ryoo, Margolis, Lee, Sandoval, \& Good, 2013). To date, 125 
students took the CS Makers course; $79 \%$ of the enrollment was minority and over $50 \%$ of the participants were female. An external evaluator investigated the impact of the program on teachers and students.

\section{Makerspaces and teacher professional development}

Project leaders developed CS curriculum, based on their curriculum logic model. The curriculum consisted of weekly lesson plans and other helpful resources (e.g. videos, power point presentations) for the teachers to support their offering of the CS Makers course, and a pacing guide for the teachers to help them determine the day-to-day coverage in teaching the course. Teachers followed the lessons at varying paces, depending on the formats of their classes. Several of the teachers were able to use the website and other resources provided to develop their own lessons.

Each participating school committed a physical space called the "makerspace" where CS Makers instruction took place. A makerspaces are collaborative workspaces inside a school where students gather to learn and explore the CS Makers course content in an experiential way. The project provided grade-appropriate CS resources for the Makerspaces. During the makerspace class period, students conducted mentored, structured, and continuous hands-on activities facilitated by teachers who participated in rigorous professional preparation in computer science education. The curriculum utilized the Micro:Bit system (Williams, 2016).

The teachers participated in intensive professional development (PD) and received regular follow-ups from the course instructors. Their PD consisted of an initial summer institute and three follow-up face-to-face workshops. The PD provided hands-on training to the teachers with topics in the CS Makers course. The presenters' team also shared pedagogical strategies with the teachers on how to teach specific CS topics. Feedback from the teachers at the workshops was used to make revisions to project resources. In addition to face-to-face meetings, periodic virtual project "check-ins" were made with teachers to learn from them about progress with course instruction, their immediate needs, and challenges with the course that we could help to address.

\section{Research methodology}

Researchers utilized a mixed method design to investigate the impact of the project on teachers and their students. The main research question was: What is the impact of the Maker-Space Project on participating middle-school teachers and their students? Qualitative methods provided an in-depth understanding of goals, objectives, expectations, and outcomes. The researchers used interviews and on-line and pencil-paper surveys to assess the short-term and long-term impact of project participation on students and teachers. The Dillman Tailored Design Method (Dillman, Smyth \& Christian, 2014) was used for the survey methodology; interviews and qualitative data collection and analysis utilized the methods suggested by Mertens (2015), Patton (2011) and Creswell, (2013a and 2013b).

\section{Findings: Impact of CS Makerspace intervention on teachers}

Measures were developed to assess attitudes and skills of teachers, as well as the specific impact of the teacher professional development (PD). Baseline teacher data on skills were collected. PD and impact data were collected at three points during the project.

The post-PD survey related to the format, curriculum, and expected outcomes of the professional development. This survey was launched by the project director following the PD sessions attended by the four teacher participants. The response rate was $100 \%$. After the professional development sessions with the project team, the teachers were very positive about what they learned and were confident in their understanding of computer science. They were optimistic about their ability to teach their students.

Teachers were asked to rate their agreement with statements related to the primary expected outcomes of the professional development. Responses were scored on a scale of 1 (strongly disagree) to 5 (strongly agree). Table 1 below shows all responses. For all questions, every participant either agreed or strongly agreed with the statement, and no item scored lower than 4.25. Agreement was strongest for ability to call on PD instructors (4.75). Agreement was weakest for learning community and importance of CS Making in $8^{\text {th }}$-grade curricula. 
Table 1. Teacher responses to ratings of items related to expected outcomes of Professional Development for the Makerspace project.

\begin{tabular}{|c|c|c|c|c|c|c|c|c|c|c|c|}
\hline Question & $\begin{array}{l}\text { Strongly } \\
\text { Disagree }\end{array}$ & & Disagree & & Neutral & & Agree & & $\begin{array}{l}\text { Strongly } \\
\text { Agree }\end{array}$ & & Mean \\
\hline $\begin{array}{l}\text { (1.1) I am confident I can } \\
\text { call on PD instructors as } \\
\text { needed. }\end{array}$ & $0.00 \%$ & 0 & $0.00 \%$ & 0 & $0.00 \%$ & 0 & $25.00 \%$ & 1 & $75.00 \%$ & 3 & 4.75 \\
\hline $\begin{array}{l}\text { (1.2) I developed a } \\
\text { learning community with } \\
\text { other teachers in the } \\
\text { group. }\end{array}$ & $0.00 \%$ & 0 & $0.00 \%$ & 0 & $0.00 \%$ & 0 & $75.00 \%$ & 3 & $25.00 \%$ & 1 & 4.25 \\
\hline $\begin{array}{l}\text { (1.3) I understand the } \\
\text { DLCS standards ( } 8 \text { th } \\
\text { grade). }\end{array}$ & $0.00 \%$ & 0 & $0.00 \%$ & 0 & $0.00 \%$ & 0 & $50.00 \%$ & 2 & $50.00 \%$ & 2 & 4.50 \\
\hline $\begin{array}{l}\text { (1.4) I understand the } \\
\text { concept of CS Making. }\end{array}$ & $0.00 \%$ & 0 & $0.00 \%$ & 0 & $0.00 \%$ & 0 & $50.00 \%$ & 2 & $50.00 \%$ & 2 & 4.50 \\
\hline $\begin{array}{l}\text { (1.5) I understand the } \\
\text { purpose of the recent } \\
\text { Professional Development } \\
\text { in CS Making. }\end{array}$ & $0.00 \%$ & 0 & $0.00 \%$ & 0 & $0.00 \%$ & 0 & $50.00 \%$ & 2 & $50.00 \%$ & 2 & 4.50 \\
\hline $\begin{array}{l}\text { (1.6) I believe in the } \\
\text { importance of CS Making } \\
\text { in } 8 \text { th grade curriculum in } \\
\text { my school. }\end{array}$ & $0.00 \%$ & 0 & $0.00 \%$ & 0 & $0.00 \%$ & 0 & $75.00 \%$ & 3 & $25.00 \%$ & 1 & 4.25 \\
\hline
\end{tabular}

The teachers reported being optimistic about their own ability to learn computer science education content and about their ability to teach the content to their $8^{\text {th }}$ grade students. They were the most confident about learning design thinking (4.50) and the Micro:Bit system (4.50) and the least confident about learning programming sequencing (3.75) and programming data abstraction (3.75). In terms of their confidence in teaching, they were most confident about design thinking (4.25), Micro: Bit (4.25) and algorithms (4.25). They were least confident about teaching programming data abstraction (3.5).

The teachers were asked about these elements of the professional development: materials, ice-breakers, lectures, individual hands-on learning activities, group hands-on learning activities, homework, pacing of the curriculum, learning space, and equipment. Responses were scored on a scale of 1 (very unhelpful) to 5 (very helpful). No participant gave a response of unhelpful or very unhelpful, and all averages were at least 4.5. The items that respondents scored as the most helpful were the materials provided by the instructors, the pacing of the curriculum, and the learning space (4.75). All other items averaged 4.5 .

\section{Findings: Teacher interviews}

Researchers interviewed teachers and students in their home schools during a Makerspace class. Students demonstrated their Micro:Bit projects at the same time. An analysis of the transcripts of the teacher interviews yielded the following findings.

All the teachers understood the mission of the project: "get kids exposed to the creative aspect of computer science"; "encourage students to pursue a career"; "get kids interested"; and "introduce kids to coding". One teacher specifically mentioned the shortage of African Americans and females in STEM. All teachers said the project would make a difference in the future (5-10 years was specified by one teacher).

When asked how participating in the project had impacted them, the teachers were very positive. Their responses had teachers several common themes:

- New skills: "better ways to instruct students for their future success"; "savvier when it comes to coding"; "more experience with engineering and other career paths"; and "I am the principal's Swiss Army knife"

- Feelings of competence and satisfaction: "more ideas about things I can do in my classes"; "feels good to help students"; "loved every bit of the program"

- New experiences: "chance to learn something new"; "continual learning process"; "teacher was learning with the student"” 


\section{Findings: Impact of the CS makerspace intervention on students}

Sixty-two students in the participating schools were surveyed during the first 3 weeks and last 3 weeks of the semester the participated in the CS Makerspace classrooms. Assessment focused on students' opinions of the CS Makerspace project, and their view of the CS Makerspace as a tool to acquire $21^{\text {st }}$ century skills (REFERENCE). Students' views of the CS Makerspace course were overall positive, with the creativity aspect of the class being the students' favorite aspect of the course. Notably, girls viewed the class as an environment that encouraged persistence, which suggests that the Makerspace intervention may be useful to engage their interest in the long term.

Students were asked, "what did you like about working in the CS Makerspace?" and given the opportunity to provide an open-ended response. Ninety-four percent (94\%) of students provided a response, and responses were analyzed for emerging themes; each response was coded as consistent with a maximum of two themes. The theme that most often emerged (from $42 \%$ boys and $46 \%$ girls) was labeled creativity, and related to building, inventing, or creating new things (sample response: "I liked to code and build things and make them move"). The second theme that emerged ( $22 \%$ boys, $10 \%$ girls) was labeled CS knowledge, and related to the acquisition of concepts related to computing (sample response: "what I liked about maker space is the algorithm"). The third theme that emerged (10\% boys, 19\% girls) was labeled class format, and related to the type of instruction received in the makerspace (sample response: "making codes and stuff with my teacher and answering questions"). Other themes that emerged were teamwork (working in teams; 7\% boys, $6 \%$ girls), and persistence (the makerspace serving to increase their work ethic or desire to succeed, $8 \%$ girls). Finally, some students answered the question stating that they liked everything about the makerspace ( $7 \%$ boys).

Students were also asked, "what didn't you like about working in the CS Makerspace?" Ninety-two percent $(92 \%)$ of students provided a response, with the most common answer being that they disliked nothing about the makerspace ( $35 \%$ boys, $40 \%$ girls). A small percentage of students mentioned a specific topic as disliked (17\% boys and girls), the difficulty of a specific assignment or task (13\% boys, $15 \%$ girls), or the time involved in completing the assignments (13\% boys, $3 \%$ girls). A small percentage of girls considered the pace of the course to be too slow $(8 \%)$, or the electronic materials available to be inadequate $(5 \%)$.

Students were asked 14 questions that referred to five constructs that align with $21^{\text {st }}$ century skills: (1) CS content, (2) working in teams, (3) persistence, (4) creativity and problem solving, and (5) initiative and responsibility. Questions for each construct were worded as "How much do you feel you learned in this course about..." and "How much do classes other than the CS makerspace teach you about..." Overall, students viewed the CS Makerspace as superior than other classes with respect to acquisition of CS concepts, learning to work in teams, persistence, and taking initiative and responsibility. Although using creativity and problem solving skills did not reach statistical significance, the CS Makerspace was rated higher than other classes in this skill too.

The teacher interviews provided insights into the impact of the classes in the middle schools on the participating students. Teachers gave examples of their students' work:

- Micro-Pet - had to pet and feed their pet.

- Games: paper-rock-scissors; Simon Says.

- The traffic light project: This was the teacher's favorite project "because it didn't work and it took about three days to figure it out, but one or two figured it out and helped the others".

- Working on robots in big groups: The teacher loved seeing students work together on the project. "Everybody was participating"; they were around the table and everybody was playing a role.

- Invented and improved games (one student invented a game with 10 levels in one week of classes; he wanted to be able to stump the teacher).

Teachers were able to give many examples of the impact of the project on their students. These are the common themes of their responses:

- Learned science/computer science/coding.

- Learned to think "outside the box".

- Were able to solve problems "student initially didn't want to solve problems, then they solved problems with their projects and they transferred this ability to other areas"; "students learned to be self-directed".

- Getting students out of their "comfort zone" / "their own bubble".

- Learned how to "get along and work collaboratively" (e.g. "working collaborative on a goal-based project" instead of looking at their phone; "to work and get along with each other".

Teachers were "very impressed with what the kids have done and how they have progressed". One teacher described approaching a working group and just watching them work collaboratively, "rolling the dice, working with algorithms". One teacher said, "The benefits for the children are 
amazing". This teacher thought it would impact the students in the future and their lives would be different in five or 10 years because of the class.

Teachers reported surprises in the impact of the project. "Students are interested because they are engaged", even students who don't start the class being interested or who were assigned to the class to fill an empty time slot in their schedule. Several teachers reported that behavior problems were minimized in the maker classroom, even with students who were "known trouble-makers". "Some students are disruptive", one teacher commented, "but get kids building and actively engaged, and their classroom behavior changes, even in other subjects".

Teachers reported students coming to class early, staying late, and using study period to work on their maker projects. One student who started out "very unmotivated" became interested and took the lead in projects. The student expressed interest in a related career in the future. One teacher said the biggest success was "students eventually realizing that they are good at this".

\section{Summary}

The CS Makerspace project developed successful Makerspaces in four middle-school classroom in Alabama. The project had a positive impact on both teachers and their students. Although the teachers varied greatly in their experience with and competency in computer science education and coding prior to the project, they were positive about their experiences with the project. The thought the Professional Development, although they stressed that it was very intensive, provided what they needed to work with their classes. They felt supported and encouraged by the project staff. Teachers reported confidence in their ability to learn the material and teach it to their students, and this confidence greatly increased after participation in the Professional Development and after they had begun implementation in their classrooms. Teachers were pleased with the responses of their students to the hands-on learning and were impressed with the Makerspace project impact on student behavior (very positive), interest (increased), and accomplishments._Teachers reported unexpected outcomes for students that included: self-direction; collaboration; minimizing behavior problems; "can't tell low level students from high level students"; creativity; problem-solving; and stellar work of female students. The researchers conclude that the CS Makerspace can be used as a valuable tool not only for acquisition of course-specific content, for middle school students and can also build important $21^{\text {st }}$ century skills.

\section{References}

American Evaluation Association (2013). American Evaluation Association Public Statement on Cultural Competence in Evaluation. Fairhaven, MA: Author. Retrieved from www.eval.org.

Creswell, J. W. (2013a). Qualitative inquiry and research design: Choosing among five traditions, $3^{\text {rd }}$ ed. Thousand Oaks, CA: Sage.

Creswell, J. W. (2013b). Qualitative Inquiry and Research Design, (3rd ed.). Los Angeles: Sage.

Dillman, D. A., Smyth, J. D., \& Christian, L. M. (2014). Internet, phone, mail, and mixed-mode surveys: The tailored design method, 4th ed. Hoboken, NJ: Wiley.

Joint Committee on Standards for Educational Evaluation (1994). The program evaluation standards: How to assess evaluations of educational programs. Thousand Oaks, CA: Sage.

Mertens, D. M. (2015). Research and Evaluation in Education and Psychology: Integrating diversity with quantitative, qualitative, and mixed methods. 4th ed. Thousand Oaks, CA: Sage.

Patton, M. Q. (2011). Developmental evaluation: Applying complexity concepts to enhance innovation and use. New York: Guilford Press.

Ryoo, J., Margolis, J., Lee, C., Sandoval, C., Goode, J. (2013). Democratizing computer science knowledge: Transforming the face of computer science through public high school education. Learning, Media and Technology, 38(2), 161-181.

Williams, W. (2016). How to... Do amazing things with the $£ 13$ BBC micro:bit. Web User, (400), 58-59, 61. 